\title{
A XILOGRAVURA COMO A PRECURSORA DA EVOLUÇÃO DAS TÉCNICAS GRÁFICAS NA PRODUÇÃO DE LIVROS
}

\section{Fernanda Silvestre Grabner ${ }^{1}$ \\ Anézio Cláudio Bernardes ${ }^{2}$}

Resumo: Este estudo diz respeito a história da impressão de livros e de todo o seu percurso evolucional. Incluindo a técnica xilográfica como base que influenciou o aperfeiçoamento dos meios tecnológicos de impressão empregados na produção de livros ao longo da história. O estudo apresenta os primórdios do homem na humanidade, retratando, primeiramente, o nascimento de sua linguagem e, posteriormente, o surgimento dos sistemas primitivos de comunicação e a capacidade de transformá-los em escrita e de transferi-los para bases materiais. A partir desse marco histórico, floresceu, no homem, o anseio de preservar os escritos para a posterioridade. Eis que surgem os meios de impressão gráfica, a partir dos quais, a xilogravura se destaca por ser o primeiro modo de multiplicação que surgiu na humanidade e, consequentemente, a responsável por todo avanço tecnológico de impressão.

Palavras-chave: Xilogravura; Técnicas gráficas; História do livro.

\footnotetext{
${ }^{1}$ FEA/Universidade do Vale do Paraíba, Brasil. E-mail: grabnerfernanda@gmail.com.

2 FEA/Universidade do Vale do Paraíba, Brasil. E-mail: abc@univap.br.
} 